\title{
Pendekatan Heutagogi: Sebuah alternatif dalam pembelajaran IPS pada masa pandemi covid-19
}

\author{
Danan Tricahyono \\ Fakultas Keguruan Ilmu Pendidikan, Universitas Sebelas Maret \\ Surakarta, Indonesia \\ danan.sejarah13@gmail.com
}

\begin{abstract}
Social studies learning has an orientation to make students as social actors who have social intelligence. The purpose of writing this article is to provide ideas on social studies learning during a pandemic with a heutagogical approach. This research uses a literature review. The researcher analyzes and compares various books and articles that have relevance to the topic of discussion. The results of the analysis and comparison are then reflected in this paper. The study results show that the heutagogical approach is a learning approach to perfect the pedagogical and andragogy approaches. The heutagogical approach gives students the freedom to design their learning - a tasteful heutagogy approach with social studies learning focuses on building students' character as lifelong learners. Considering that this article is limited to a literature review, it is recommended that further research be conducted with qualitative and quantitative studies to see how much influence the heutagogical approach has in social studies learning.
\end{abstract}

Keywords: heutagogy; IPS; Covid-19

\begin{abstract}
Abstrak
Pembelajaran IPS memiliki orientasi menjadikan peserta didik sebagai aktor sosial yang memiliki kecerdasan sosial. Penulisan artikel ini memiliki tujuan untuk memberikan gagasan pada pembelajaran IPS di masa pandemi dengan pendekatan heutagogi. Penelitian ini menggunakan kajian pustaka. Peneliti menganalisis dan membandingkan berbagai buku dan artikel yang memiliki relevansi dengan topik bahasan. Hasil analisis dan perbandingan kemudian direfleksikan dalam tulisan ini. Hasil penelitian menunjukkan bahwa pendekatan heutagogi merupakan pendekatan pembelajaran untuk menyempurnakan pendekatan pedagogi dan andragogi. Pendekatan heutagogi memberikan kebebasan kepada peserta didik untuk mendesain pembelajarannya. Pendekatan heutagogi selaras dengan pembelajaran IPS yang fokus pada pembentukan karakter peserta didik sebagai pelajar sepanjang hayat. Mengingat artikel ini sebatas pada kajian pustaka maka direkomendasikan untuk dilakukan penelitian lebih lanjut dengan studi kualitatif dan kuantitatif guna melihat seberapa besar pengaruh dari pendekatan heutagogi dalam pembelajaran IPS.
\end{abstract}

Kata Kunci: heutagogi; IPS; Covid-19 


\section{Pendekatan Heutagogi: Sebuah Alternatif ...}

Diterima 04 Oktober 2021, Dipublikasikan 30 Oktober 2021

\section{PENDAHULUAN}

Pandemi covid-19 telah mengubah berbagai pola kehidupan manusia. Salah satunya bidang pendidikan yang ujung tombaknya adalah kegiatan belajar dan pembelajaran di kelas. Hal ini juga berlaku pada pembelajaran IPS. Sebelum pandemi covid-19 kegiatan belajar-mengajar dilakukan dengan tatap muka atau dalam istilah saat ini dikenal dengan luring (luar jaringan). Kedatangan pandemi covid-19 berdampak pada berubahnya iklim pembelajaran menjadi sistem daring (dalam jaringan) dan hibrid. Perubahan sistem pembelajaran menjadi daring dan hibrid memiliki pengaruh positif dan negatif terhadap aspek psikologis peserta didik. Dalam penelitiannya (Sani, Turnip, Fausiah, Jagadhita, \& Farassania (2020) menguraikan bahwa pengaruh tersebut dapat dilihat dari sisi emosi dan perilaku, trauma, serta kesejahteraan psikologi. Dari sisi emosi dan perilaku bisa dilihat untuk peserta didik yang belajar dari rumah menunjukkan tingkat masalah emosi dan perilaku yang lebih rendah ketika dibandingkan dengan belajar hibrid dan tatap muka penuh. Dari sisi trauma peserta didik yang melakukan pembelajaran hibrid menunjukkan gejala trauma yang tinggi jika dibandingkan dengan belajar dari rumah maupun tatap muka. Dari sisi kesejahteraan psikologi peserta didik yang belajar dari rumah menunjukkan tingkat yang paling tinggi jika dibandingkan dengan belajar hibrid dan tatap muka. Penelitian tersebut memberikan gambaran jika pandemi covid-19 berpengaruh terhadap aspek psikologis peserta didik bahkan juga guru.

Guru selama pandemi covid-19 belum semuanya menyajikan pembelajaran secara ideal. Guru yang belum terbiasa dengan sistem daring akan lebih sering memberikan tugas-tugas kepada peserta didik. Hal diperkuat oleh penelitian dari Febiani \& Nisa (2021) yang memberikan kondisi pembelajaran IPS pada masa pandemi covid19 guru memanfaatkan aplikasi berupa google classroom, whatapps grup, dan telegram. Melalui media tersebut guru tidak memberikan sintak pembelajaran. Guru memulai pembelajaran dengan salam via whatsapp grup kemudian peserta didik disuruh presensi melalui google clasroom. Proses berikutnya guru memberikan perintah kepada peserta didik untuk membaca materi dan diakhiri dengan menjawab kuis atau tugas. Pemberian materi biasanya melalui link youtube. Guru hanya hadir sekitar 10-20 menit kemudian peserta didik dilepas begitu saja. Kemungkinan permasalahan pembelajaran daring yang belum optimal disebabkan oleh kurangnya pemahaman guru terkait konsep pembelajaran yang mesti dilakukan (Aji, 2020). Kondisi demikian ini tentu akan menjauhkan peserta didik dengan tujuan pembelajaran. Arah dari mata pelajaran IPS sesuai dengan Kurikulum 2013 fokus pada pembentukan pengetahuan, sikap, dan keterampilan ditambah dengan penguasaan TIK sebagai bekal menghadapi tantangan abad 21 (Safitri, 2019).

Posisi IPS sebagai mata pelajaran memiliki luaran membentuk insan-insan manusia dengan kecerdasan sosial yang baik. Hal ini sebagaimana diungkapkan oleh penelitian dari (Nurfidia (2016) bahwa IPS memiliki posisi penting untuk menunjang terbentuknya generasi yang peka terhadap lingkungan sosial. Alasannya berdasar pada komposisi IPS yang diperoleh dari 
integrasi dan pengorganisasian dari beberapa disiplin ilmu seperti geografi, sosiologi, ekonomi, dan sejarah. Hasil pengintegrasian dari beberapa disiplin ilmu tadi kemudian diintegrasikan kembali dengan kondisi sosial masyarakat yang dipelajari secara pedagogis dan psikologis sesuai dengan perkembangan peserta didik demi tercapainya tujuan pembelajaran. Hakikat dari tujuan pembelajaran IPS menjadikan peserta didik memiliki kesadaran yang dibalut dengan komitmen terhadap nilai-nilai sosial dan kemanusiaan yang terwujud dalam sikap humanisme (Akob \& Wibowo, 2015).

Humanisme penting dimiliki oleh peserta didik sebagai calon generasi penerus bangsa. Birsyada (2016) dalam bukunya dasar-dasar pendidikan IPS menjelaskan bahwa pelajaran bertujuan untuk menjadikan peserta didik memiliki sikap sosial yang baik dalam hubungannya dengan masyarakat. Sikap sosial tersebut tercermin dari interaksi dan sosialisasi dengan masyarakat. Para peserta didik yang menghayati nilai-nilai dalam pelajaran IPS akan memiliki habituasi untuk senantiasa bersikap memanusiakan manusia. Masalahnya belum semua pembelajaran IPS disajikan dengan berorientasi pada pembentukan sikap sosial yang unggul. Salah satu titik pangkalnya bisa jadi pendekatan pembelajarannya belum sesuai dengan tujuan pembelajaran. Ditambah lagi dengan kondisi pandemi covid-19 mengharuskan pembelajaran dilakukan dengan daring melalui whatsapp, youtube dan google clasroom.

Pembelajaran melalui platform online bisa menjadi tantangan sekaligus peluang. Ketika platform whatsapp, youtube dan google clasroom maupun platform yang lain hanya digunakan sebagai sarana pemberian tugas tanpa dibarengi dengan penyampaian materi serta pendampingan yang optimal maka pembelajaran IPS akan menjadi tidak bermakna. Hal ini diperkuat oleh penelitian dari Fajriyah \& Itaqullah (2021) yang menjelaskan jika pembelajaran IPS dengan sistem daring berpengaruh terhadap motivasi dan minat dari peserta didik yang menurun. Kondisi demikian harus diberikan alternatif. Salah satunya dengan memilih pendekatan yang sesuai dengan karakteristik peserta didik dan iklim pembelajaran online. Artikel ini bertujuan memberikan alternatif dengan pendekatan heutagogi dalam pembelajaran IPS di masa pandemi covid-19. Manfaat dari penelitian diharapkan menginspirasi bagi para guru IPS untuk menciptakan pembelajaran IPS dengan pendekatan heutagogi sehingga luaran hasil yang menjadikan peserta didik sebagai pribadi yang memiliki kecerdasan sosial bisa terwujud.

\section{METODE}

Penelitian ini menggunakan riset kepustakaan. Penelitian kepustakaan dilakukan dengan melalui proses mengkaji berbagai karya tulis. Peneliti menggunakan buku dan dokumen tertulis hasil penelitian yang termuat dalam jurnal ilmiah maupun artikel. Pemilihan sumber tersebut dengan mempertimbangkan isi serta relevansinya dalam rangka mendukung dalam proses penelitian (Agung, 1992). Langkah yang peneliti lakukan dengan menganalisis data-data yang telah terkumpul dari berbagai dokumen. Proses analisis dilakukan untuk menemukan informasi yang diperlukan guna mendukung topik penelitian. Riset kepustakaan dilakukan dengan 


\section{Pendekatan Heutagogi: Sebuah Alternatif ...}

memanfaatkan buku dari perpustakaan maupun laporan hasil penelitian. Riset kepustakaan yang peneliti lakukan terbatas pada analisis bahan-bahan koleksi perpustakaan saja tanpa memerlukan riset lapangan (Zed, 2008).

Pemilihan sumber pustaka untuk menunjang penelitian dilakukan secara teliti dan cermat. Peneliti menggunakan tujuh buku, sepuluh artikel jurnal, dan tiga artikel konseptual. Peneliti melalukan verifikasi sumber atau kritik sumber yang digunakan sehingga benar-benar memiliki kredibilitas. Mengingat dalam penelitian kepustakaan sumber yang digunakan lebih ke sumber sekunder maka batasan penentuan sumber dilakukan dengan lebih menekankan pada kritik internal yang berhubungan dengan latar belakang penulis dan isi tulisannya benar-benar berdasar pada teori yang tepat. Sehingga karya yang dihasilkan memiliki kualitas dan kuantitas yang nantinya dapat dipertanggungjawabkan secara akademik. Setelah data penelitian terkumpul, berikutnya ditempuh langkah berupa merangkum inti tulisan (annotated bibliography) (Indriati, 2005). Kegiatan pencatatan diperlukan untuk mempermudah peneliti dalam mengingat data yang ditemukan. Sehingga jika terdapat kekurangan data akan mencari sumber yang sama. Maka pada saat menuliskan sumber diharapkan menuliskan data dengan lengkap seperti judul, penulis, dan tahun terbit. Data yang telah dikumpulkan kemudian dikelompokkan berdasarkan aspek keterhubungan dengan topik penelitian. Berikutnya peneliti melakukan pengecekan tentang keabsahan dan kredibilitas data yang dibutuhkan sampai proses penafsiran. Data yang telah ditafsirkan kemudian direfleksikan dalam bentuk tulisan sebagai berikut ini. Riset kepustakaan dilakukan untuk memecahkan atau mencari solusi untuk masalah yang sedang diteliti.

\section{HASIL DAN PEMBAHASAN}

\section{Pendekatan Heutagogy Dalam Pembelajaran IPS}

Heutagogy secara terminologi merupakan pembelajaran yang ditentukan secara mandiri oleh si pembelajar. Secara konsep heutagogi sebagai pendekatan yang holistik. Maksudnya pendekatan pembelajaran yang memuat rangkaian perencanaan, tindakan, dan evaluasi secara berkesinambungan. Dalam pendekatan heutagogi proses belajar merupakan kegiatan aktif dan pro aktif di mana peserta didik ditempatkan sebagai agen pembelajar yang mendesain pembelajaran secara mandiri (Blaschke Lisa Marie, 2012). Posisi guru sebagai seorang pendidik sebatas sebagai konsultan yang memberikan sumber daya dan bimbingan. Mengenai proses pembelajaran, terjadinya negosiasi pembelajaran sampai dengan materi yang akan dipelajari serta bagaimana akan belajar dengan materi tersebut ditentukan oleh peserta didik (Hiryanto, 2017). Pendekatan heutagogi memberikan opsi kepada guru dan peserta didik melakukan kolaborasi secara aktif. Tentu kolaborasi yang dilakukan lebih menonjolkan peran peserta didik sebagai agen pembelajaran. Guru berperan sebagai pemantik proses belajar supaya jalan yang dipilih oleh para peserta didik tidak berakhir menyesatkan dirinya. Di antara peserta didik dan guru bisa melakukan tukar pikiran mengenai apa yang pas untuk dipelajari 


\section{Danan Tricahyono}

oleh peserta didik dan memilih sintak pembelajaran beserta sumber belajar demi tercapainya tujuan pembelajaran.

Heutagogi sangat menarik jika dipilih sebagai pendekatan dalam pembelajaran IPS. Hal ini tidak lepas dari cara pandang yang diajukannya tentang konsep si peserta didik sebagai agen pembelajar aktif yang sejalan dengan tujuan pendidikan IPS untuk mengembangkan kepribadian peserta didik agar menjadi aktor sosial yang cerdas (Riyani, 2015). Membelajarkan peserta didik dengan kondisi perkembangan psikologisnya yang masih labil menjadi tantangan tersendiri. Mengingat membelajarkan IPS orientasinya adalah praksis dan aplikatif. Guru-guru IPS memiliki peran untuk menghadirkan praktik sosial materi kajian IPS untuk diimplementasikan peserta didik pada kehidupan nyata. Maka setiap sajian pembelajaran IPS perlu dipertimbangkan betul. Kondisi pandemi covid-19 yang mengharuskan pembelajaran daring menjadi tempat yang tepat untuk menerapkan pendekatan heutagogy.

Pandemi covid-19 memberikan dampak pembelajaran terlaksana dengan jarak jauh. Kondisi demikian berpengaruh terhadap pengawasan guru kepada peserta didik. Tidak ada yang bisa memastikan ketika peserta didik diberikan tugas melalui whatsapp atau google clasroom para peserta didik benar-benar bertanggungjawab atas tugas yang diberikan. Kondisi demikian perlu disikapi oleh guru dengan bijak. Mengingat tujuan dari pembelajaran IPS menjadikan para peserta didik sebagai aktor sosial yang cerdas. Maka pendekatan heutagogi dapat dipilih dalam penyelenggaraan pembelajaran jarah jauh. Guru memberikan arahan kepada para peserta didik untuk merancang kegiatan pembelajarannya secara mandiri. Guru sebagai konsultannya yang berperan pada sesi terakhir melakukan evaluasi bersama-sama dengan peserta didik. Poin penting dari implementasi pendekatan heutagogi adalah pemilihan materi yang harus tepat. Mengingat mata pelajaran IPS materinya terdiri dari integrasi dari geografi, sosiologi, ekonomi, dan sejarah. Kiranya guru dapat menentukan pada sub materi yang mana yang bisa dipilih.

Secara konsep heutagogi merupakan kepanjangan dari pedagogi dan andragogi. Pedagogi menekankan hubungan guru dan peserta didik. Andragogi lebih digunakan pada proses pembelajaran orang dewasa. Pada pendidikan formal andragogi biasa digunakan pada level menengah. Sementara pendekatan heutagogi sebagai perkembangan dari andragogi bisa digunakan untuk jenjang menengah sampai pendidikan tinggi. Di mana untuk peserta didiknya lebih dewasa dan sedikit membutuhkan kontrol dari guru. Meskipun demikian dalam penerapan konsep, pendekatan heutagogi pada pelaksanaan pembelajaran tidak mesti mutlak pada bentuk, satuan tingkat dan level pendidikan (Hiryanto, 2017). Akan tetapi yang penting sekaligus aspek mendasar adalah kesiapan pada peserta didiknya. Guru harus cermat melihat potensi yang di ada dalam diri masing-masing peserta didik. Kondisi peserta didik pada dasarnya bisa diasumsikan sebagai orang dewasa yang memiliki kemampuan aktif dalam merencanakan arah belajar, memiliki bahan, dan berpikir cara terbaik untuk belajar, menganalisis dan menyimpulkan serta mengambil manfaat dari belajar. Apabila secara kondisi 


\section{Pendekatan Heutagogi: Sebuah Alternatif ...}

psikologis sebuah kelas telah siap untuk menggunakan pendekatan heutagogi tidak ada salahnya untuk dicoba.

Hal mendasar yang perlu menjadi perhatian guru mengenai pendekatan heutagogi adalah kemiripannya dengan teori belajar konstruktivisme. Di antara keduanya orientasinya adalah pembelajaran yang berpusat pada peserta didik. Di antara keduanya memiliki persamaan dalam memandang bahwa pembelajar merupakan individu yang sekaligus mampu merekonstruksi sendiri pengetahuannya melalui proses keaktifannya dalam belajar. Selain itu juga dalam pembelajaran konstruktivisme dan pendekatan heutagogi fokus utama sama yaitu pada belajarnya pembelajar, bukan pada mengajarnya guru (Ridha, 2018). Tetapi, jika dicermati lebih detail di antara keduanya berbeda. Perbedaan tersebut dapat dilihat konsep yang ditawarkan teori belajar konstruktivisme. Dalam pembelajaran konstruktivisme peserta didik dari segi kebebasan masih kurang. Peserta tidak diperkenankan untuk mendesain pembelajarannya.

Pembelajaran konstruktivisme dari segi desain pembelajarannya masih berada dipegang oleh guru. Peserta didik hanya menjalankan secara mandiri. Pilihan yang tersedia menjadi satusatunya opsi untuk dipilih. Sisi positifnya konstruktivisme memberikan kebebasan pada peserta didik untuk aktif merekonstruksi pengetahuannya melalui berbagai aktivitas dalam pembelajaran. Peserta didik bukan menjadi pribadi yang pasif menerima penjelasan dari guru. Sementara konsep heutagogi begitu jelas yaitu dengan memberikan kebebasan kepada sejak awal pada peserta didik guna menentukan tentang materi yang akan dipelajari, metode mempelajari serta pembuktiannya jika peserta didik telah menguasai kompetensi tertentu, walaupun dalam menentukan proses tersebut keterlibatan guru sebagai konsultan belajar masih ada (Kamrozzaman, Badusah, \& Wan Mohammad, 2019).

Berikut ilustrasi segitiga kesiapan belajar.

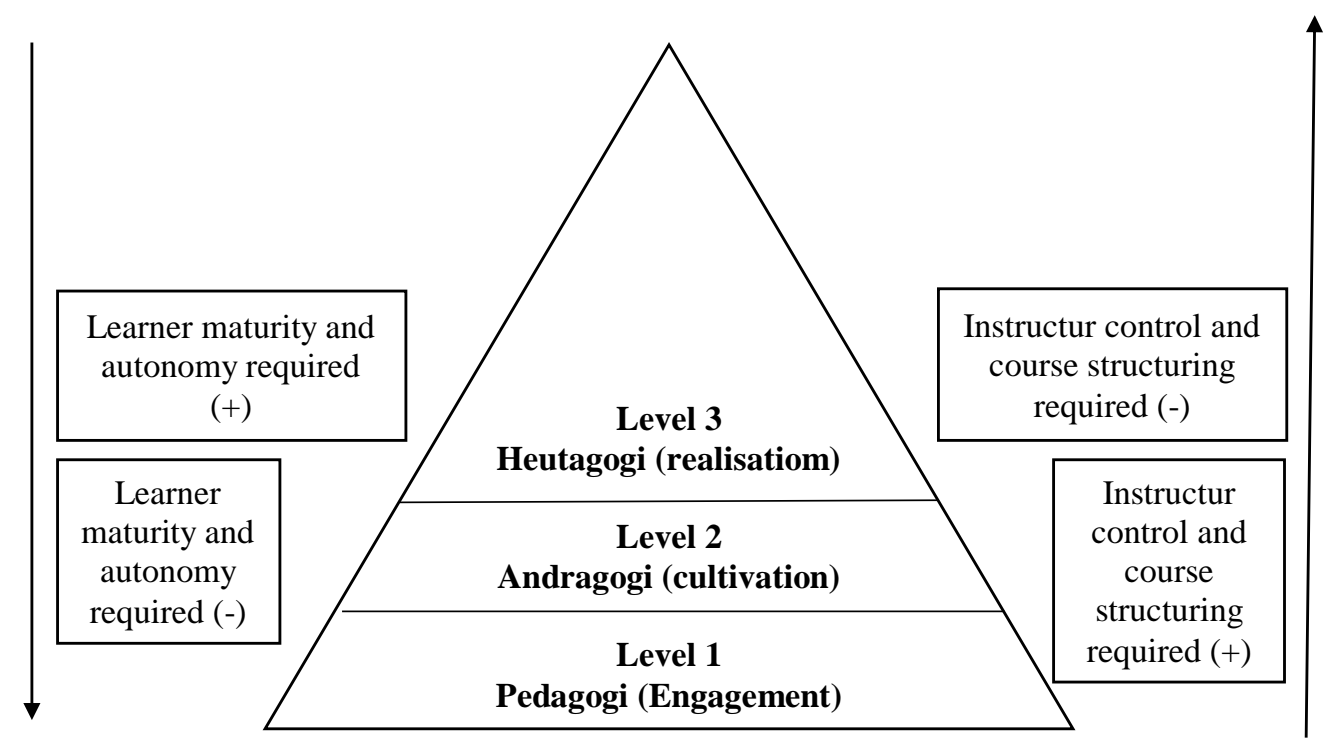

Gambar 1. Segitiga Kesiapan Belajar (Hiryanto, 2017) 
Mengacu pada gambar di atas, dapat dijelaskan jika hubungan pedagogi, andragogi, dan heutagogi ditinjau dari kematangan peserta didik dan kemandirian belajar. Pedagogi berada di level 1, andragogi berada di level 2, dan heutagogi berada di level 3. Level tersebut menunjukkan jika semakin tinggi levelnya maka semakin tinggi kemandirian belajarnya sementara keterlibatan guru sebagai instruktur materi pembelajaran semakin berkurang. Sementara semakin levelnya turun maka kemandirian belajar dan peran guru sebagai instruktur pembelajaran semakin dominan. Pada implementasi pedagogi peran guru sangat dominan dibandingkan dengan peserta didik (Sulistya, 2019). Pada dasarnya penerapan heutagogi dapat menjanjikan kesuksesan pada pembelajaran IPS yang orientasinya menjadikan para peserta didik memiliki kecerdasan sosial. Semua itu bisa maksimal apabila subjek belajarnya memiliki tingkat kemandirian dan kematangan belajar yang cukup. Hal ini dibuktikan dengan bekal visi belajar yang jelas dan kemampuan untuk memahami gaya belajar yang sesuai dengan individu peserta didik. Apabila hal-hal tersebut belum ada dalam diri peserta didik akan memberikan hambatan saat menentukan materi mana yang mesti dipelajari, cara untuk mempelajari serta membuktikan pada guru jika peserta telah menguasai materi tertentu.

Pendekatan heutagogi memiliki beberapa keunggulan yaitu kemampuan berpikir kritis serta reflektif peserta didik menjadi berkembang, motivasi belajarnya akan berkembang, mendorong pertumbuhan dan pemberdayaan pribadi, kepekaan terhadap isu di sekitarnya menjadi bertambah yang luarannya menjadikannya berusaha menerapkan pengetahuannya pada kondisi nyata di kehidupannya. Kemampuan demikian akan menjadikan kepercayaan diri peserta didik meningkat. Sehingga kelak peserta didik ketika telah dewasa dapat hidup di berbagai lingkungan dengan berbagai latar karakter. Mengingat peserta didik memiliki kemampuan adaptif yang baik. (Bashori, 2020). Hal ini sangat linier dengan IPS. Sebagaimana pendapat Barth (1990) yang menjelaskan jika pembelajaran IPS idealnya mengajak peserta didik menyelami keadaan sosial lingkungan sosial masyarakatnya secara riil. Konsekuensinya materi IPS berisi tentang tema-tema persoalan sosial yang akan dipahamkan dan coba untuk dipecahkan bersama-sama pada peserta didik. Pendekatan heutagogi juga mengembangkan keterampilan kerja tim dan manajemen proyek. Orientasi heutagogi tidak berhenti pada penguasaan suatu kompetensi tertentu, akan tetapi juga adanya peningkatan kapasitas dan kapabilitas kompetensi tersebut. Hal ini bermakna luaran dari implementasi pendekatan heutagogi adalah menghasilkan generasi yang terus berkembang dengan berpijak pada kompetensi dan kapabilitasnya untuk diterapkan pada berbagai keadaan lingkungan yang dinamis sehingga dikenal dengan generasi pembelajar belajar sepanjang hayat.

Amanah kurikulum 2013 yang menekankan pembelajaran abad 21 dengan kemampuan 4C (critical thinking, creativity, communication, dan collaboration) maka kemampuan metakognitif harus mulai diajarkan sejak tingkat menengah pertama. Mengingat generasi muda Indonesia hari ini masih mengalami kebingungan akan menjadi apa dirinya di masa depan bahkan buta akan hal yang harus dicapai dan dilakukannya di masa depan. Masalah kurangnya 


\section{Pendekatan Heutagogi: Sebuah Alternatif ...}

pemahaman terkait tujuan hidup, memilih gaya belajar secara tidak langsung berpengaruh terhadap usaha-usaha peserta didik dalam pengembangan dirinya, baik yang berhubungan dengan kepribadian, kompetensi serta kapasitas dan kapabilitasnya (Riyadi, 2015).

Tahapan implementasi pendekatan heutagogis adalah merancang kontrak belajar. Peneliti mencoba memberikan contoh dalam tataran praktisnya. Dimulai dengan peserta didik berkonsultasi pada guru. Tahap ini peserta didik dan guru berkolaborasi mengidentifikasi kebutuhan belajar dan tujuan yang diharapkan dari belajar. Maka rumusan pertanyaan yang harus dijawab berhubungan dengan peserta didik ingin belajar apa?, peserta didik memperoleh hasil apa dari belajar, secara spesifik kebutuhan kurikulum apa yang dibutuhkan?. Kegiatan penyusunan kontrak belajar memiliki dampak positif memudahkan peserta didik menentukan apa yang dipelajari serta jalan yang dilalui guna menuntaskan proses pembelajaran. Peneliti berikan contohnya pendekatan heutagogi diterapkan di kelas IX pada materi sosiologi. Pada dasarnya pendekatan heutagogis akan terlaksana lebih optimal apabila kurikulumnya fleksibel. Maksudnya menyesuaikan dengan motivasi dari peserta didik.

Poin pentingnya peserta didik membuat kurikulum secara sederhana sendiri, dengan memperhatikan pada penyesuaian terhadap kebutuhan masing-masing. Misal peneliti mengambil pada kompetensi dasar (KD) 3.2 Menganalisis perubahan kehidupan sosial budaya Bangsa Indonesia dalam menghadapi arus globalisasi untuk memperkokoh kehidupan kebangsaan. Berikutnya pada kompetensi dasar (KD) 4.2 Menyajikan hasil analisis tentang perubahan kehidupan sosial budaya Bangsa Indonesia dalam menghadapi arus globalisasi untuk memperkokoh kehidupan kebangsaan. Dari kompetensi dasar tersebut peserta didik menetapkan materi yang ingin dipelajari. Terdapat peserta didik yang ingin belajar perubahan sosial budaya dalam konteks di sekitarnya, Terdapat peserta didik belajar lebih spesifik pengaruh globalisasi dalam berbagai bidang kehidupan di sekitarnya seperti ekonomi dan kebudayaan, Terdapat peserta didik yang belajar pengaruh positif dan negatif globalisasi terhadap kebangsaan, terdapat peserta didik yang belajar cara menyikapi globalisasi supaya memperkokoh kehidupan kebangsaan. Dari berbagai materi tersebut para peserta didik diberi kebebasan untuk bagaimana mereka belajar. Sebagaimana telah disebutkan pada pemaparannya sebelumnya jika tujuan IPS menjadikan peserta didik menjadi pribadi yang memiliki kecerdasan sosial maka lebih direkomendasikan belajar dengan mengambil kasus yang berada di sekitarnya.

Tahapan terakhir setelah proses belajar adalah evaluasi. Tahapan evaluasi merupakan langkah yang tidak boleh dilewatkan. Tahapan ini untuk mengukur ketercapaian hasil belajarnya. Pada pendekatan heutagogi peserta didik membuat secara mandiri penilaian belajarnya. Peserta didik boleh memilih akan menilai aspek kognitifnya, afektif, maupun keterampilannya. Peneliti memberikan saran dengan menggunakan penilaian diri. Jenis penilaian tersebut memiliki keunggulan melatih peserta didik untuk bersikap jujur dan meningkatkan kemampuan refleksi dan mawas diri (Kemedikbud, 2017). Melalui penilaian diri akan memberikan kesan jika belajar terasa menyenangkan dan memacu peserta didik untuk 
belajar lebih dalam lagi. Pada sesi penutup guru memiliki tugas untuk mengkonfirmasi terkait ketercapaian kontrak belajar. Keuntungan pendekatan heutagogi yang bersifat independen dapat memunculkan konflik batin pada peserta didik khususnya bagi mereka yang belum terbiasa belajar secara mandiri (Bashori, 2020). Akan tetapi jika peserta didik telah terbiasa belajar secara mandiri menjadikan mereka sulit kembali ke struktur kurikulum yang kaku. Pendekatan heutagogi juga memfasilitasi para peserta didik saling bekerja sama, berbagi pengetahuan, merefleksikan kemajuan, serta berpikir bagaimana menerapkan itu semuanya pada tataran praksis. Sehingga heutagogi sebagai pendekatan pembelajaran mendorong peserta didik untuk terus belajar di manapun dan kapanpun. Melalui heutagogi akan menghasilkan sumber daya manusia yang tangguh dengan kemampuan adaptif yang baik sehingga bisa diterima di berbagai lingkungan. Hal ini telah dibuktikan dengan penelitian Khoeriyah (2019) yang dilakukan di Al-Luqmaniyyah Boarding School. Hasil penelitiannya menunjukkan bahwa kemandirian hasil belajar pada saat di sekolah bisa diterapkan di lingkungan masyarakat, seperti melakukan pembelajaran Al-Qur'an di masyarakat. Hal ini juga bisa terjadi pada pembelajaran IPS dengan terlatih melakukan pembelajaran mandiri akan menjadikan peserta didik berperan aktif berperan dalam kehidupan masyarakat seperti terlibat dalam kegiatan sosial.

\section{SIMPULAN}

Heutagogi merupakan pendekatan pembelajaran yang memberi otonomi penuh kepada peserta didik untuk mendesain pembelajarannya. Para peserta didik diberikan kesempatan menentukan materi yang akan dipelajari, menentukan proses mempelajari, sampai mengevaluasi yang telah dipelajari. Posisi guru sebagai konsultan pembelajaran. Guru memiliki peran mengarahkan supaya yang dipelajari oleh peserta didik tidak keluar dari kurikulum. Implementasi pendekatan heutagogi dalam pembelajaran IPS selaras dengan tujuan dari IPS untuk menghasilkan generasi muda yang memiliki kecerdasan sosial. Pendekatan heutagogi memiliki keunggulan dalam membentuk kepekaan sosial peserta didik. Persinggungan peserta didik dengan lingkungan untuk memulai belajar berpengaruh terhadap kebermaknaan hasil belajarnya. Maka pandemi covid-19 yang awalnya menjadi hambatan interaksi peserta didik dengan teman sebaya maupun guru dapat diganti dengan interaksi peserta didik dengan lingkungannya. Kebiasaan peserta didik untuk peka terhadap lingkungan berdampak pada sensitivitas ketika mengetahui maupun bersinggungan dengan masalah sosial. Harapannya ketika peserta didik bertemu dengan masalah sosial bisa memberikan solusi sekaligus belajar untuk meningkatkan kualitas dan kapabilitasnya sebagai seorang pembelajar sepanjang hayat.

\section{DAFTAR PUSTAKA}

Agung, I. G. . (1992). Metode Penelitian Sosial (Pengertian dan Pemakaian Praktis). Jakarta: Gramedia Pustaka Utama. 


\section{Pendekatan Heutagogi: Sebuah Alternatif ...}

Aji, R. H. S. (2020). Dampak Covid-19 pada Pendidikan di Indonesia: Sekolah, Keterampilan, dan Proses Pembelajaran. SALAM: Jurnal Sosial Dan Budaya Syar-I, 7(5), 395-402. https://doi.org/10.15408/sjsbs.v7i5.15314

Akob, B., \& Wibowo, G. A. (2015). Pembelajaran Multikultural Pada Siswa SMP Sebagai Upayaa Meningkatkan Nasionalisme. Seuneubok Lada, 2(1), 34-52.

Barth, J. . (1990). Methods of Instruction in Social Science Education. New York: University Press of America.

Bashori, K. (2020). HEUTAGOGI. Retrieved August 31, 2021, from https://mediaindonesia.com/opini/309932/heutagogi Mei 2020

Birsyada, M. I. (2016). Dasar-Dasar Pendidikan IPS (Suatu Pendekatan Teoritis dan Praktis). Yogyakarta: Ombak.

Blaschke Lisa Marie. (2012). Heutagogy and Lifelong Learning: A Review of Heutagogical Practice and Self Determined Learning. International Review of Research in Open and Distance Learning, 13(1), 56-71.

Fajriyah, I., \& Itaqullah, V. B. P. (2021). Analisis Pembelajaran IPS Daring Pada Masa Pandemi Covid-19 Di SMP Negeri 2 Tarik Sidoarjo. Artefak, 8(2).

Febiani, M., \& Nisa, A. N. S. (2021). Analisis Aktivitas Pembelajaran IPS Berbasis Daring Pada Masa Pandemi Covid-19 Bagi Peserta Didik Smp Di Kecamatan Tahunan Kabupaten Jepara. Harmony, 6(1), 72-79. Retrieved from https://journal.unnes.ac.id/sju/index.php/harmony/article/view/41826

Hiryanto. (2017). Pedagogi, Andragogi, dan Heutagogi Serta Implikasinya Dalam Pemberdayaan Masyarakat. Dinamika Pendidikan, 22(1), 65-71.

Indriati, E. (2005). Menulis Karya Ilmiah: Artikel, Skripsi, Tesis, dan Disertasi. Jakarta: Gramedia Pustaka Utama.

Kamrozzaman, N. A., Badusah, J., \& Wan Mohammad, W. M. R. (2019). Heutagogy Approach: Effectiveness of M-Learning For Lifelong Learning Education. Sains Humanika, 11(3), 53-61. https://doi.org/10.11113/sh.v11n3.1496

Kemedikbud. (2017). Panduan Penilaian Oleh Pendidik dan Satuan Pendidikan untuk Sekolah Menengah Pertama. Jakarta: Kementerian Pendidikan dan Kebudayaan Direktorat Jenderal Pendidikan Dasar dan Menengah Direktorat Pembinaan Sekolah Menengah Pertama.

Khoeriyah, M. (2019). Heutagogy in the Course of Pesantren Education (Case Study At Pesantren Salaf Al-Luqmaniyyah). International Journal on Islamic Educational Research, 3(1), 66-79. https://doi.org/10.14421/skijier.2019.2019.31.07

Nurfidia, A. (2016). Menumbuhkan Sikap Empati Siswa Dengan Menggunakan Metode Role Model Dalam Pembelajaran IPS (Penelitian Tindakan Kelas di SMP 44 Bandung di Kelas VII A). International Journal Pdagogy of Social Studies, 1(1), 1-18.

Ridha, M. (2018). Heutagogi dan Arah Pendidikan 4.0 Kita. Retrieved August 17, 2021, from https://geotimes.id/opini/heutagogi-dan-arah-pendidikan-4-0-kita/

Riyadi, S. (2015). Model Pembelajaran Berbasis Metakognisi Untuk Peningkatan Kompetensi Siswa Pada Mata Pelajaran IPS. Yogyakarta: Depublish.

Riyani, M. (2015). Pendidikan IPS Sebagai Katalisator Dalam Transformasi Pendidikan Di Indonesia (Penerapan Paradigma Sosialis pada IPS Sebagai Counter Attack Terhadap Kecenderungan Paradigma Materialisme). Ilmu Ilmu Sejarah, Sosial, Budaya Kependidikan, 2(1), 1-15. 
Safitri, M. (2019). Keterampilan Abad 21 Dalam Pembelajaran IPS.

Sani, A. S., Turnip, S. S., Fausiah, F., Jagadhita, D. A., \& Farassania, G. (2020). Gambaran Kondisi Psikologis Siswa di Indonesia pada Masa Pandemi COVID-19: Analisis Berdasarkan Cara Pembelajaran dan Jenjang Pendidikan. In Ikatan Psikolog Klinis Indonesia. Retrieved from https://ipkindonesia.or.id/media/2020/12/Gambaran-KondisiPsikologis-Siswa-di-Masa-Pandemi-15Des2020.pdf

Sulistya, R. (2019). Heutagogi Sebagai Pendekatan Pelatihan Bagi Guru Di Era Revolusi

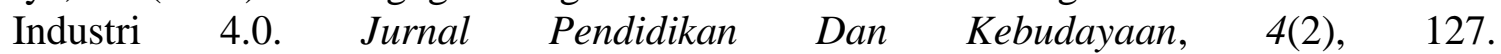
https://doi.org/10.24832/jpnk.v4i2.1222

Zed, M. (2008). Metode Penelitian Kepustakaan. Jakarta: Yayasan Obor Indonesia. 